José Guilherme Merquior, Ministro de segunda classe de carreira diplomática, membro da Academia

Brasileira de Letras e Assessor do

Gabinete Civil da Presidência da

República.

\title{
Guerra ao homo oeconomicus
}

Convido o leitor a fazer comigo uma excursão informal pela terra das ciências humanas. Mais precisamente, pelo território daquilo que os anglosaxões chamam de 'teoria social'. Para pôr sal e pimenta no passeio, escolhi como seu propósito tarefa algo detetivesca. Trata-se de descobrir, no atual panorama das idéias filosófico-sociológicas, quem deseja assassinar o homo oeconomicus! Pois não há dúvida: o pobre sujeito, apesar de ser apenas um ente de razão, e ainda por cima vastamente mitificado, encontra-se em perigo de morte. Várias correntes de pensamento, das mais prestigiosas nestas últimas décadas, revelam-se decididas a abatê-lo a tiros... A imagem do indivíduo calculador, imbuído de racionalidade instrumental - a Zweckrationalität de Max Weber - é cada vez mais pintada como uma mutilação moral, e, ao mesmo tempo, como verdadeira aberração metodológica em ciência social.

Essas correntes situam-se em pelo menos sete disciplinas: na sociologia, graças à conhecida teoria da sociedade pós-industrial; na ética e filosofia social, com a obra de John Rawls; em teoria política, com C. B. Macpherson; na teoria do conhecimento e na filosofia da cultura, com Jürgen Habermas; na economia política da nova escola de Cambridge, descendente intelectual de Piero Sraffa; na antropologia econômica institucionalista dos discípulos de Karl Polanyi; e, finalmente, na antropologia cultural comparatista de Louis Dumont.

Em todos esses casos, estamos diante de inimigos jurados da idéia do homo oeconomicus. 0 que proponho é um exame sintético, porém não superficial, dos argumentos mobilizados por essas posições teóricas, a fim de podermos ajuizar seu ânimo 'antieconomista'. Mas antes de passar a esse exame crítico, convém dizer duas palavras sobre a verdadeira natureza do homo oeconomicus - pois o fato é que seus denunciantes costumam caricaturá-lo além dos limites.

Vejamos, portanto, qual a sua face autêntica. Há de certo modo um senso intuitivo do homo oeconomicus. Ele se reporta a duas tradições intelectuais: a economia clássica e o utilitarismo. O homo oeconomicus é antes de tudo o herói de Adam Smith e do cálculo 'felicífico' de Bentham - uma figura moral legitimada há dois séculos pela Riqueza das nações e pelo Fragmento sobre o governo, ambos de 1776. Tal figura sucedia ao ideal aristocrático da honra, à virtù renascentista, ao homo religiosus do puritanismo e, enfim, ao libertino hedonista reprimido durante a cultura barroca e em seguida liberado na era do rococó. Note-se que o libertino não é necessariamente um utilitarista; Bentham era o primeiro a admitir que o cálculo da satisfação individual pode assumir formas pouco ou nada hedonista. No fim da idade das luzes, esse tipo moral do homo oeconomicus conhecerá alguns êmulos: o cidadão de civismo exaltado, à Saint-Just; o virtuoso seguidor do imperativo categórico segundo Kant; e a alma bela de Schiller, formada pela autocultura, a Bildung, do classicismo alemão.

O impacto ideológico dessa tríplice emulação numa boa parte da consciência burguesa desde a revolução francesa explica, em larga medida, a má reputação do homo oeconomicus já entre nossos avós vitorianos. Tanto o revolucionário, o rigorista ético quanto o esteticista ou boêmio dedicarão um desprezo colossal a todo cálculo utilitário. A paranóia jacobina, o formalismo moralista e o narcisismo 'humanista' da alma bela condenarão juntos a sórdida 'estreiteza' da visão moral dos economistas bur- 
gueses e seus confrades, os filósofos utilitaristas. É acusação predominante em toda uma ampla literatura, até os nietzscheanos da Belle Époque tipo Spengler, que excomungavam com volúpia as baixezas do 'anglomaterialismo'...

Aparentemente, nada disso concerne às ciências sociais. Mas na realidade elas não escaparam à marca do espírito antiutilitarista. Haja vista Durkheim, um dos principais fundadores da sociologia, grão-sacerdote da crítica ao utilitarismo e ao individualismo que ele implica. Entretanto, até ontem, o substrato ideológico da ciência social, em seu conjunto, não denotava a repulsa aguda e generalizada da atualidade. $O$ antiutilitarismó de Durkheim não foi o elemento determinante na influência de sua obra na formação da teoria sociológica. A rigor, a fúria 'economicida' é o fenômeno recente, sendo para lá de significativo que se mostre disposta a invadir até mesmo o bastião originário e mais sólido do homo oeconomicus - a própria ciência econômica.

E o mais curioso é que, em tudo isso, o homo oeconomicus se faz vítima do maior equívoco. Ele é acusado de ser escravo das satisfações mais grosseiras, um filistino sem gosto nem coração, como o Père Grandet de Balzac ou o Josiah Bounderby de Dickens... Vai-se ver, e nosso homem nada tem desse vil materialista, maníaco do ignóbil. Na verdade, a imagem do homem proposta pela análise econômica e pelas abordagens análogas é, simplesmente, a de um 'seletor', "Ao contrário da suposição corrente, a economia nunca encarou ninguém como um maximizador com um objetivo único, correspondente ao 'estereótipo' do homo oeconomicus. Se essa pessoa obsessiva existisse, a única coisa que ela 'não' seria é precisamente um homem econômico, porque tal individuo nunca enfrentaria um problema de escolha" (D. Seckler) - e escolher é, justamente, o que o homo oeconomicus sempre faz.

O decisivo, nesse ponto, é que o faz movido pelas finalidades mais diversas. Nada exclui - ao contrário - que o alvo dileto de seu desejo esteja entre os mais humanos e nobres: um amor terno ou sublime, um ideal heróico, uma devocão desinteressada, etc. Pois o homem econômico, bom benthamiano, não conhece hierarquias axiológicas a priori; pode exercer seu cálculo sobre qualquer gênero de valores.

E se ele não é, por definição, nem herói nem santo, 'é só por definição que não é' - nada o impede de vir a sê-lo, sem que para isso tenha que negar sua natureza. A única condição é que 'escolha' conscientemente no tocante à relação meio/fim e, naturalmente, calcule as perdas e danos que essa escolha possa acarretar do ponto de vista de 'outros' valores. Em resumo: o que define a conduta do 'ho- mem econômico' não é a qualidade de seus objetivos - é apenas a lucidez do seu agir.

No mais, o homem econômico não é apenas uma imagem do homem - é também um tipo ideal de análise do comportamento humano. É o que veremos a seguir, antes de passar à avaliação crítica das ideologias 'economicidas' nas ciências humanas de nosso tempo.

O homo oeconomicus não é apenas um tipo moral - constitui também um modelo de análise. Modelo encontradiço desde Adam Smith, e que ocupa um lugar estratégico na explicação sociológica lato sensu. Raymond Boudon, em livro recente, indicou a que ponto vários paradigmas clássicos da análise sociológica repousam na mecânica calculatória da racionalidade instrumental, cerne do comportamento econômico.

O primeiro desses paradigmas é ilustrado pela conduta dos capitalistas de Marx, no terceiro livro do Capital. Os capitalistas buscam o lucro por meio da competição; verificando que a produtividade aumenta, investem em maquinaria mais eficaz; ao fazê-lo, fazem crescer a parte do capital fixo, e não a do capital variável, proveniente da mais-valia. Conseqüência: baixa tendencial da taxa do lucro, pondo em risco a própria sobrevivência do sistema.

Segundo paradigma: os aristocratas franceses contrastados com seus congêneres ingleses em O Antigo regime e a revolução, de Tocqueville. Enquanto, na França, os nobres e a alta burguesia eram atraídos pela venalidade dos cargos públicos - a possibilidade de comprar elegar altos empregos no estado - na Inglaterra, onde as camadas superiores da sociedade não sofriam esse tipo de sedução, investiu-se com muito maior empenho na capitalização da agricultura. O resultado levou, num caso, ao enrijecimento dos privilégios, provocando a revolução social; no outro, ao triunfo do capitalismo, preparado pela emergência de uma aristocracia economicamente ativa.

Terceiro paradigma: os puritanos da Ética protestante e o espírito do capitalismo, de Max Weber. Socializados pela soteriologia calvinista, isto é, pela doutrina da salvação da alma baseada no dogma da predestinação e de seus indícios mundanos, os puritanos organizavam sua vida de maneira metódica, a um só tempo ascética e realista - o que lhes proporcionou a aquisição de hábitos extraordinariamente favoráveis à poupança e à racionalização da atividade econômica, levando à expansão do capitalismo.

Que há de comum entre esses três ilustres exemplos de explicação sociológica? Todos eles descrevem efeitos 'não desejados', provocados por ações perfeitamente racionais. De fato, os capitalis- 
tas de Marx evidentemente não desejavam a ruína do capitalismo causada pela baixa da taxa de lucro. A nobreza funcionária de Tocqueville não anelava a revolução. E os puritanos de Weber tampouco visavam ao estabelecimento do capitalismo. Todos eles criaram, sem saber, processos históricos altamente irônicos.

Por outro lado, os três paradigmas diferem entre si pela ausência ou presença de elementos 'fora' da ação racional deflagrada pelos atores. Tanto os aristocratas de Tocqueville quanto os puritanos de Weber agem em contexto moldado por um elemento 'estranho à ação'. Para os primeiros, esse elemento consiste na existência de cargos públicos compráveis, que pautarão a escolha dos atores. Já no caso dos puritanos de Weber, esse elemento prévio atua por assim dizer por detrás da ação, pois se confunde com o próprio tipo de socialização vivido pelos puritanos, logo, com algo preexistente às suas decisões no sentido de organizar a vida. Esse algo não consta do paradigma de Marx, cujos componentes pertencem todos ao próprio agir.

Já se disse que, enquanto a economia estuda a ação racional, a sociólogia encontra seu maior interesse no deslindamento de complexos de ação marcados pela superveniência de efeitos 'inintencionais', o que leva muitos a sublinharem a 'irracionalidade' do comportamento social focalizado pela sociologia. Porém é importante observar que a emergência de resultados não previstos - de 'efeitos perversos' - absolutamente rão anula a presença do cálculo racional na origem das condutas identificadas com processos sociais do vulto e conseqüência dos que acabamos de mencionar. Nas análises de Tocqueville, Marx e Wéber, deparamos sempre com o homo oeconomicus como unidade analítica, porque, nos três casos estamos lidando com atores voltados para 'escolhas', ditadas pela consideração racional (pelo menos a curto prazo) da relação meio/fim. É nesse sentido que o homo oeconomicus funciona como arquiparadigma da ciência social.

De resto, trata-se de paradigma que acaba de receber reforços bem revigorantes. Aqui mesmo indicamos como a utilização do cálculo de racionalidade do rendimento da terra serviu à história econômica revisionista de North e Thomas, especialmente no tocante às causas do colapso do feudalismo e do decisivo surto de capitalismo agrário que precedeu, no noroeste da Europa, os primeiros passos da revolução industrial. O foco da 'nova história econômica' de North e Thomas não recai, como nos exemplos clássicos citados por Boudon, nas ironias da história; mas a base de suas explorações é a mesma: em ambos os casos, parte-se, para explicar a mudança social, das escolhas racionais dos indivíduos.
Mas a ressurreição do homo oeconomicus como instrumento metodológico não se limita aos estudos históricos. Ela permeia também uma fecunda perspectiva de expansão da própria análise econômica: a 'teoria do capital humano', elaborada por Gary Becker, e inteligentemente divulgada, no mundo latino, pelos livros de Henry Lepage. Discipulo de Milton Friedman, Becker se tornou, como seu mestre, luminar da escola de Chicago. Human capital é de 1964; a influente coletânea The Economic approach to human behavior, de 1976.

Tudo teve início quando Friedman rejeitou a noção do consumidor como criatura passiva, restrita a realizar escolhas ad hoc, e salientou as opç̃es 'intertemporais' do consumo, as quais não dependem apenas da renda atual das pessoas, refletindo ao contrário a renda futura do consumidor, 'antecipada' pelo calculador que ele é. Becker desenvolve essa idéia. Mostra que, na verdade, o consumidor, além de consumir, também produz: produz sua própria satisfação. E para produzi-la, não usa só os ingredientes que adquire no mercado. Usa, igualmente outro recurso escasso, até aqui basicamente desprezado pela teoria econômica: o 'tempo'.

Os críticos da sociedade de consumo costumam censurar a superfluidade 'alienada' do grande número de objetos que cercàm a população dos países ricos (as democracias industriais) e as camadas mais favorecidas dos que imitam a sua 'economia afluente'. A teoria do capital humano vê as coisas com outros olhos. Numa economia em que, a longo prazo, a produtividade está em constante aumento, os salários também se elevam regularmente. Isso significa que cada hora de trabalho proporciona ao assalariado os meios de dotar-se de um volume crescente de bens e serviços, e, portanto, de obter um nivel crescente de satisfação por unidade de tempo. Assim, a 'mania do consumo' é, no fundamental, perfeitamente racional - pois o que ocorre é que o preço das mercadorias não cessa de diminuir 'relativamente ao preço do nosso tempo'.

Uma virtude da teoria do capital humano em sua capacidade de aplicação a uma esfera da conduta - as interações sociais - que os adversários da ciência econômica sempre tenderam a considerar refratário ao modelo analítico da economia. Por exemplo, Becker estendeu suas investigações à família, encarando-a como unidade de produção, exatamente como se fosse empresa. Suas demonstrações revelam, em minúcia, os mecanismos que regem a evolução do emprego feminino. Por que o número de mulheres casadas que trabalham fora é bem menor que o das solteiras? Porque os salários pagos às mulheres são, geral e injustamente, mais baixos que os dos homens; e porque (em países ricos, onde a criadagem é praticamente inexistente) a 
mulher, na realidade, trabalha no lar, numa espécie de divisão conjugal do trabalho, que maximiza o potencial produtivo de cada família nuclear. Com o número crescente de mulheres empregadas, os diferenciais do salário entre os sexos se vão estreitando, reduzindo-se, em conseqüência, as vantagens materiais do casamento. Nos Estados Unidos, onde vem aumentando sensivelmente a proporção de solteiros em relação à população global, essa é a tendência - ainda aqui, essencialmente explicável em termos da análise 'utilitarista' do homo oeconomicus $^{\prime} \ldots$

Deixemos neste ponto nossa rememoração dos aspectos positivos do homo oeconomicus. A seguir começaremos a focalizar os argumentos das teorias hostis a esse modelo - as teorias que, juntas, compõem o que chamamos de 'ideologia economicida'.

Havendo resgatado a valia do homo oeconomicus enquanto figura moral e enquanto modelo de análise sociológica, passemos à consideração dos argumentos das teorias 'economicidas'.

A primeira delas, em nossa enumeração anterior, é a chamada teoria da sociedade pós-industrial. Esquematicamente, assinala-se a emergência, já bem avançada nos Estados Unidos, porém esbocada em todo o resto do mundo industrial adiantado, de uma 'sociedade de serviços', marcada por um modo de consumo cada vez menos materialista, pelo triunfo da 'qualidade da vida' e pelo reino do conhecimento. Em semelhante sociedade, a especialização tecnológica tende a substituir em toda a parte o trabalho não qualificado, e a educação prevalece sobre a propriedade como fonte de poder.

O evangelho da sociologia pós-industrial continua a ser a obra de Daniel Bell, cuja influência, como seu teorizador, ultrapassa de longe a do francês Alain Touraine. Mas é lícito aproximar as teses do conhecido sociólogo de Harvard de autores como $\mathrm{E}$. Schumacher (Small is beautifun), do Galbraith de Economics and the public purpose e do Dahrendorf de The New liberty, para não falar nos Social limits of growth de Fred Hirsch. Todos esses livros, publicados no curso dos anos setenta, respiram repulsa ao ethos produtivista, privatista e consumidor do homem ocidental, em nome dos valores mais altose mais públicos do 'social'.

Bell está convencido de que, na economia de serviços do pós-industrialismo, o modo econômico, reificado e reificante, está cedendo lugar à mentalidade 'sociologizante' de uma nova 'ética da comunidade', de vocação claramente anticapitalista. A seu ver, é preciso 'separar o liberalismo político da sociedade burguesa'. Esta última seria uma forma social nitidamente ultrapassada, e o tom dos pós-indus- trialistas chega mesmo a lembrar o catastrofismo daqueles que, como R. Heilbroner, falam do desmoronamento da 'civilização do negócio'. No entanto, Bell nada tem de pessimista. Contempla sem remorso a perspectiva de um fim do capitalismo, mas saúda jubilosamente o advento de uma sociedade de serviço; pois os serviços, nota ele, são 'jogos entre pessoas' e não, como no consumo reificado da sociedade industrial, uma relação entre homem e coisa.

Schumacher não vacilou em subscrever os oráculos do Clube de Roma. Pouco antes de morrer, propunha uma utopia liliputiana baseada numa economia 'budista'... Tratava-se de um saudosista do artesanato, inimigo feroz da sociedade de consumo. Galbraith e Hirsch são mais contidos em matéria de utopismo, mas comungam na crítica de princípio ao consumo privado ilimitado. Quanto a Dahrendorf, opõe o melhoramento (improvement) ao crescimento e denuncia a cupidez das 'classes industriais': os proprietários e o salariado das corporations, que, ávidos de lucro e de salários mais altos, permanecem hipnotizados pela 'mania do crescimento'.

O problema é que a base empírica da profecia pós-iñdustrial é bem pouco sólida. Para começar, a teoria pós-industrialista envolve alguns sérios equívocos quanto à natureza da estrutura social do capitalismo avançado. Tende, por exemplo, a superestimar a ocupação em detrimento da posição de classe. E também se engana sobre as próprias mudanças ocupacionais: assim, a transferência das mulheres do trabalho doméstico para serviços fora do lar costuma ser incluída arbitrariamente no cômputo do movimento geral do setor secundário para o terciário.

Além disso, os profetas do pós-industrialismo esquecem habitualmente que muito emprego terciário (mais da metade, na Grã-Bretanha) não pertence realmente às atividades proporcionadoras de servicos no sentido de 'jogos entre pessoas', mas sim às atividades - como a distribuição, o banco, os seguros - estreitamente ligadas à produção de bens materiais. Em conseqüência, em muitos casos, o terciário não passa de um apêndice do setor secundário, ou seja, da esfera da produção.

Porém isso não é tudo. J. Gershuny levantou uma crítica ainda mais calibrada. Observou que a tese pós-industrialista do advento de uma economia de serviço 'confunde, pura e simplesmente, a dinâmica do emprego com a dinâmica do consumo'. Do fato de que o salariado ocidental se concentra cada vez mais no setor terciário, os sociólogos pós-industriais deduzem que os serviços estão substituindo os bens materiais no consumo. Mas isso não é o que dizem as estatísticas. Estas mostram que, em lugar de multiplicar sempre compras de serviços, as famílias 
das democracias industriais cada vez mais adquirem bens duráveis que permitem a seus compradores produzir serviços por e para si mesmos. A tendência mais forte é para a generalização da substituição da lavanderia pela máquina de lavar, ou do curso de línguas pelo linguafone, etc. Numa palavra o emprego pode estar crescendo mais no terciário do que na indústria; mas o consumo permanece em grande parte orientado para bens, e não serviços - mesmo quando se trata de bens produtores de serviços.

De resto, não é fácil pensar nos habitantes dessa sociedade self-service como seres pouco individualistas, pouco privatistas e antiutilitários. A gente rica dos suburbia americanos parece bem menos inclinada à nostalgia da comunidade do que os sociólogos e economistas de Harvard ou da Inglaterra. A bem dizer, com sua mentalidade antieconômica, esses teóricos fazem figura de espíritos mais 'pré-industriais' que verdadeiramente pós-industriais. Tudo bem pesado, nossa primeira teoria alérgica ao homo oeconomicus revela que o antieconomismo é muito mais postura ideológica do que o resultado de análise objetiva do mundo atual.

A seguir examinaremos uma teoria economicida que, ao contrário da sociologia pós-industrial, não se quer analítica, e sim normativa - a ética de John Rawls, autor do tratado de moral le de moral social) mais influente dos últimos dez anos: $A$ Theory of justice.

A Teoria da justiça de John Rawls (1972) constitui a obra mais influente na ética e na filosofia social dos últimos anos. Tecnicamente, trata-se de renovação da perspectiva 'contratualista', eixo das teorias do contato social à Locke e à Rousseau. A novidade de Rawls, nesse quadro conceitual, reside na decisão de descrever as pessoas que tomam parte no contrato social como se elas se encontrassem numa 'posição original' caracterizada por um 'véu de ignorância' no tocante às preferências e interesses particulares de cada um.

Em semelhante posição, argumenta Rawls, se as pessoas são racionais e só pensam no próprio interesse, elas serão logo levadas a adotar dois principios de justiça, ou melhor, de eqüidade (justice as fairness). Primeiro, cada membro da sociedade deve usufruir tanta liberdade quanto compatível com uma quantidade igual de liberdade para outrem. Em segundo lugar, toda desigualdade deve ser em benefício dos menos privilegiados entre os socii. Segundo Rawls, os indivíduos colocados sob 'véu de ignorância', sendo muito moderados em seu altruísmo, preferirão tais princípios porque estes traduzem um critério 'maximin': na incerteza das conseqüências de suas escolhas, as pessoas quererão sempre 'minimizar' a possibilidade de serem prejudicadas, e, portanto, optarão por uma 'maximização' deste ris$\mathrm{Co}$, garantindo que cada desigualdade redunde em vantagem para os menos abastados entre os membros do pacto social. O maximin é, em suma, uma cláusula de prudência - um seguro moral.

Rawls considera sua concepção de hipotética cegueira originária uma espécie de 'interpretação processual' do conceito kantiano de imperativo categórico. A seu ver, o véu de ignorância recobre egos numerais que exprimem sua natureza enquanto membros racionais e iguais de um universo moral inteligível. Na segunda parte de seu tratado, consagrada às instituições, torna-se evidente que o autor busca estabelecer uma ordem liberal onde o elemento geralmente associado ao liberalismo econômico passa para o segundo plano, à medida que conotações igualitaristas ganham relevo.

Entretanto, para igualitaristas na tradição anarco-cooperativista - a tradição que remonta a Godwin e, no século passado, o Proudhon, Kropótkin e William Morris, e que está representada, no pensamento anglo-saxão, pela linha que vai do socialismo cristão de Tawney a R.M. Titmuss, seu último profeta na London School of Economics - a eqüidade raw/siana não é suficiente. Certos críticos não vacilam em atribuir a Rawls um igualitarismo superficial, muito aquém de uma verdadeira justiça distributiva. Outros 'progressistas', como C. B. Macpherson, salientam a miopia de Rawls diante das situações de classe, e acusam a concepção contratualista de sacrificar demasiado a uma imagem 'consumista' do ser humano; a justiça raw/siana não passaria duma idealização do capitalismo liberal americano.

Mas essas críticas de esquerda aceitam sem pestanejar uma componente central na teoria de Rawls: sua rejeição do utilitarismo. De fato, Rawls separa nitidamente sua idéia da justiça, que é 'deontológica', da moral utilitarista, que é 'teleológica'. A primeira estipula deveres; a segunda, fins identificados com desejos individuais. Nosso filósofo não esconde que sua regra de eqüidade 'impõe restrições' às concepções do bem pessoal. Ao mesmo tempo, censura o hábito utilitarista de raciocinar como se a justiça fosse apenas uma projeção social do princípio da escolha individual.

Ora, o utilitarismo permanece a grande justificação da liberdade como liberdade de escolha. Por isso é que ele conserva da ética clássica uma teoria 'cognitiva' dos valores, ao mesmo tempo em que lhe dá uma interpretação naturalista, isto é, não transcendental. Já a moral do imperativo categórico, a que se filia Rawls, suprime o fundamento cognitivo dos valores e da moralidade, além de restaurar uma hierarquia - o primado da razão sobre as paixões - 
contra a qual, precisamente, se rebelou a inspiração libertária do utilitarismo clássico.

Outrora, o furor antiutilitarista era a marca da ideologia conservadora, tanto em moral quanto em política. Acaso esse furor se tornou apanágio de um 'progressismo' - o socializante - nutrido da suspeita generalizada face à diversidade dos apetites e paixões do homem?...

Finalmente, qual seria a aplicabilidade da ética de Rawls às sociedades industriais? A prioridade dada por Rawis à liberdade (sua primeira regra de justiça) sobre a igualdade (segunda regra) é geralmente interpretada como uma aceitação do modelo liberal de sociedade. Infelizmente, porém, os sociólogos estimam esse metro conceitual para aferir a justiça das instituições liberais muito ingênuo frente à complexidade da sociedade moderna. Complexa, esta última encerra com freqüência efeitos perversos devidos à agregação não intencional de comportamentos que, não obstante, seria bem pouco liberal reprimir. Por exemplo, a liberdade individual de escolher seu nível de instrução figura entre as causas principais da... persistência das desigualdades.

Talvez seja injusto considerar a ética de Rawls uma simples idealização do welfare state capitalista - mas é certo que ela não nos satisfaz como instrumento de controle da legitimidade numa ordem social desprovida de regulação central de tipo autoritário. Teoria antiutilitarista da escolha, a moral do maximin postula, segundo Daniel Bell (que, sob outros aspectos, a admira) , um estado estacionário da economia. Que melhor exemplo da síndrome economicida do que essa linda combinação de recalcitrância antiindividualista e resistência ao dinamismo econômico?

A seguir a teoria política mais característica do economicídio: a obra de Macpherson.

Como a ética social de Rawls, a teoria da democracia do canadense C. B. Macpherson (The Life and time of liberal democracy, 1977) é doutrina economicida de cunho normativo e não descritivo.

Macpherson examina quatro concepções da democracia. A primeira, proveniente do utilitarismo clássico, benthamiano, baseia-se numa noção do homem como animal competitivo, propenso a maximizar desejos potencialmente infinitos. No segundo conceito de democracia, ao contrário - conceito ilustrado sobretudo por John Stuart Mill - o homem aspira principalmente a desenvolver suas faculdades; deixa de ser um consumidor possessivo e predatório lo individualismo possessivo sendo a bête noire de Macpherson) para se tornar um ser em busca de auto-aperfeiçoamento. No entanto, esse segundo modelo democrático permanece muito pouco igualitário, ainda próximo à mentalidade do mercado.

Na terceira concepção, a pluralista, devida a Robert Dahl, a democracia consiste numa competição entre elites. A participação das massas é desencorajada e a inspiração moral do democratismo clássico abandonada. É justamente a participação, na moldura, mas não nas formas do liberalismo político que usufruimos em nossas democracias industriais, que define o quarto modelo democrático, advogado pelo próprio Macpherson.

Acentuar a participação das massas possui pelo menos o mérito de superar a posição inicial de Macpherson, o qual, em livros anteriores, como The Real world of democracy (1966), tendia a reduzir a democracia à sua dimensão social. A pretexto de fidelidade aos clássicos, e particularmente a Aristóteles, nosso teórico costumava acentuar que democracia significava originalmente 'governo por ou no interesse da classe oprimida'. Já foi mostrado o equívoco desse 'ou': para Aristóteles, a democracia depende antes de tudo do político. Democracia queria dizer governo da maioria e 'por conseguinte' - sendo a maioria pobre - governo pelos pobres. Mas o aspecto essencial era o político, não o social. A igualdade fundamental era a política. Isso não quer dizer que as outras dimensões da desigualdade não condicionem, às vezes gravemente, a igualdade política: mas nos proíbe, sem sombra de dúvida, de falar de democracia, como fazia Macpherson, nos casos em que a igualdade política não desempenha nenhum papel sério. Por exemplo: nas chamadas 'democracias populares'.

Porém tanto na sua versão primitiva quanto na atual, participatória, o democratismo macphersoniano se obstina em ser ferozmente antiutilitário. Macpherson deplora ruidosamente o desejo de consumo, o fato de que as massas burguesas preferem 'o conforto à comunidade'. No fundo de sua raiva antiutilitarista, encontra-se caricatura, muito bem denunciada por Kenneth Minogue. Com efeito, a tese segundo a qual não há limites para os desejos individuais (o tema de Hobbes e de Bentham) não é, a rigor, uma 'descrição' da empiria social; é ûma proposição 'constitutiva', destinada a evitar uma regulamentação artificial dos negócios humanos. Na realidade de todos os dias, é óbvio que os homens não são tão cúpidos nem tão vorazes.

Mas essa caricatura do consumismo pode ter implicações políticas altamente repressivas. A despeito da apologia cívica da participação, o modelo político macphersoniano insinua uma redução autoritária do consumo. Ora, toda redução desse tipo, quer diretamente restritiva, quer sutilmente educativa, cheira a liberticídio; pois ela deixaria em suspenso a questão decisiva: quem educará os educado- 
res? Uma vez que se trata de escolher - e de escoIher uma opção prévia às nossas próprias escolhas individuais - com que direito alguém, ou alguns, escolherão em nosso lugar? Mais uma vez, o ataque contra o utilitarismo contém perigo para a liberdade.

Entre o descritivo e o normativo, deparamos com outra prestigiosa doutrina economicida: a 'teoria crítica' da escola de Frankfurt, sociologizada por Jürgen Habermas. A sociologia pós-industrialista pretende, conforme vimos, derivar o fim do econômico da ultrapassagem da estrutura social do industrialismo. Para o sociólogo, o interesse da obra de Habermas reside em que ele procura situar essa superação 'muito mais cedo' na escala da evolução social. A seu ver, o eclipse do primado do econômico data do advento do "capitalismo tardio" (Spätkapitalismus), na volta do último século. Naquelaépoca, o estado começou a se envolver na economia e a ciência virou uma força de produção. A partir de então, a própria evolução industrial tornou caduca a crítica da economia política - o projeto de Marx como instrumento de análise e emancipação. Hoje em dia, o papel emancipatório da teoria migrou para o domínio do cultural, reservatório das motivações necessárias à legitimação da ordem burguesa, que contém atualmente o potencial de ruptura com os desempenhos reclamados pela maquinaria social alienante do capitalismo.

É claro que esse comentário não cobre todo o perfil do pensamento de Habermas. Contudo, para nossos propósitos, basta assinalar o quanto Habermas se esforça por desvalorizar a 'ação instrumental' - precisamente o tipo de conduta inerente ao homo oeconomicus como tipo moral e modelo epistemológico. Toda a crítica habermasiana está presidida pela dicotomia trabalho/interação, teorizada em estreita analogia com a oposição entre techne e praxis, ou ainda regra instrumental/norma axiológica. Em última análise, Habermas termina por dissociar a dominação do fenômeno de classe, para identificá-la com uma paisagem cultural definida pela preponderância da técnica sobre a interação, e da razão instrumental sobre o diálogo, concebido como esfera interativa liberta de toda racionalidade de tipo objetivista.

Assim, uma tênue utopia - a socialidade como conversação - serve, em Habermas, de reprise do vetusto tema pedagógico do idealismo alemão; e é somente a esse preço que o filósofo tenta escapar ao Kulturpessimismus dos primeiros teóricos de Frankfurt, Horkheimer e Adorno.

Culturalismo acabado, a 'teoria crítica' se afasta sensivelmente da fecunda estratégia analítica sintetizada pela idéia de infra-estrutura - e que designa, como quer Raymond Aron, não uma afirmação dogmática de 'instâncias' determinantes, mas ape- nas o senso dos condicionamentos e determinismos fora do qual nenhuma explicação sociológica pode progredir. O significado central da filosofia de $\mathrm{Ha}$ bermas é justamente esse: celebrar as núpcias do 'marxismo ocidental', revisto e corrigido, com uma posição assumidamente neo-idealista, que passa obrigatoriamente pela desvalorização moral e cognitiva do econômico, afetado de um valor negativo, de subumanidade. Sob a roupagem de uma antropologia filosófica e uma filosofia da história, alternativa para o materialismo de Marx, o que Habermas nos propõe é, pura e simplesmente, a própria metafísica da ideologia economicida.

Depois de ter procurado detectar o germe economicida na teoria da sociedade pós-industrial, na filosofia social de Rawls, no conceito de democracia de Macpherson e na 'teoria crítica' de Habermas, o atual corifeu da escola de Frankfurt, vejamos rapidamente que papel desempenha o antieconomismo em duas outras correntes teóricas: a economia da nova escola de Cambridge e a antropologia econômica de Karl Polanyi e seus discípulos. O interesse do nosso exercício crítico reside, obviamente, na circunstância dessas duas correntes estarem localizadas exatamente no próprio terreno da economia, isto é, onde, em princípio, menos seria de esperar a ocorrência de motivos ideológicos definidos pela hostilidade ao homo oeconomicus.

Comecemos pelos economistas nouvelle vague de Cambridge. Eles trabalham com conclusões derivadas, no essencial, da análise neo-ricardiana elabora por Piero Sraffa em Produção de mercadorias por meio de mercadorias (Cambridge, 1960). Sraffa é um personagem tão secreto quanto carismático, que conseguiu fascinar Keynes e Wittgenstein após ter dado provas de uma nobre lealdade para com Gramsci, quando este curtia as prisões fascistas. O objetivo de seu pequeno livro (menos de cem páginas) concebido quarenta anos antes de sua edição, é solucionar um problema suscitado por Ricardo, o maior dos economistas clássicos: como determinar uma medida constante do valor, quer dizer, um critério para medir os preços de produção que reflitam unicamente variações na técnica de produção? À diferença de Marx, Sraffa calcula a taxa de lucro e o preço relativo das mercadorias por meio de hipóteses sem nada a ver com a troca de mercadorias regida pela quantidade de trabalho nelas incorporadas (mais-valia). Sua solução consiste em isolar uma 'matéria-prima padrão', equivalente à função do trigo no Ensaio sobre o/ucro de Ricardo, onde esse produto preenche as condições supra mencionadas.

Não teremos aqui a pretensão de criticar o raciocínio sraffiano, cuja excessiva abstração tem sido bastante censurada (ver por exemplo, Mark Blaug, 
The Cambridge revolution: success or failure, 1975). O que nos importa é a conclusão principal: a idéia de que o produto nacional, em termos físicos e em termos de valor, absolutamente 'não' é afetado pela maneira pela qual o produto líquido esteja distribuído entre salários e lucros. Tal é, com efeito, o ponto sublinhado por Joan Robinson, e em seguida por todos os tenores da atual escola de Cambridge: a distribuição da renda é 'economicamente indeterminada', resultando tão somente da luta de classes. Segundo esses jovens turcos, na expressão 'economia política', a escola neoclássica, matriz teórica do ensino dominante na disciplina, negligenciou demais o adjetivo. Ora, se a distribuição não é conseqüência de uma troca, é preciso levar em conta, antes de tudo, o fator político. Como diz Edward Nell: "a economia ortodoxa tenta mostrar que os mercados atribuem recursos escassos segundo a eficácia relativa; a economia política tenta mostrar que os mercados distribuem a renda de acordo com relações de poder".

Em última análise, a concepção sraffiana abole a tradicional mistério da 'transformação' da maisvalia em lucro, cerne da problemática de Marx e sede do elemento metafísico e 'escolástico' (como bem viu Schumpeter) na sua "crítica da economia política". Mas essa vantagem é desperdiçada pela introdução de aspectos indeterministas e impalpáveis na explicação econômica. Com a escola de Cambridge, o pensamento economicida consegue sua mais bela proeza: chegar a vencer a lógica do econômico no seio da própria teoria econômica!...

Passemos agora à antropologia econômica, em sua teorização mais recente. A perspectiva dos autores mais influentes: Claude Meillassoux, Maurice Godelier, Marshall Sahlins reportam-se abundamente à obra pioneira de Karl Polanyi (1886-1964), o fundador da perspectiva 'institucionalista' nesse terreno. Polanyi era um socialista hipnotizado pela idéia de comunidade. Suas teses centrais em economia comparada equivalem a uma espécie de desenvolvimento histórico-antropológico da concepção ariștotélica da economia. Como Aristóteles, Polanyi acreditava na existência de formas 'naturais' de atividade econômica e, em particular, de troca. Estudando a Atenas clássica, ele repôs no circuito a distinção entre a metadosis, troca natural porque entre produtores, e a chrematistikè, comércio antinatural, porque conduzido por mercadores não produtores.

Todo o polanyismo se resume nisso. A subordinação do econômico ao social, alvo do comunismo segundo Marx, era na verdade, para Polanyi, a regra do conjunto da evolução histórica. A única grande exceção - a 'sociedade de mercado' do liberalismo econômico vitoriano - teria sido apenas uma aberração, responsável, num efeito de bumerangue, pelas taras políticas de nosso tempo, a começar pelos fascismos lé a tese de seu livro mais famoso, The Great transformation, 1944). Acima de tudo, Polanyi privilegiava sempre os contextos de 'distribuição' da riqueza, afastando-se nitidamente, dessa forma, do papel central atribuído pelo marxismo às relações de produção. Tanto maior a ironia de vê-lo hoje assimilado e entronizado por antropólogos que se querem marxistas ou marxizantes...

A mensagem polanyiana é clara. A autonomia do econômico não teria sido senão uma breve anomalia histórica. Ainda mais fortemente que em Habermas, o primado do político impera, banindo toda presunção de explicar a história por meio de uma causalidade econômica. A lógica da racionalidade econômica, potencialidade natural do agir humano, não passa, para os polanyismos, de um fenômeno basicamente teratológico, espécie de perversão da ação social. Assim, apesar do valor heurístico, exploratório, de suas pesquisas comparatistas, Polanyi sacrificou demais à ideologia do antieconomismo. O homem que denunciou 'nossa mentalidade mercantil ultrapassada' era ele próprio possuído por uma economofobia singularmente arcaica, cujas origens ideológicas remontam às nostalgias literárias do anticapitalismo romântico. Por isso mesmo, não se vê como seria possível utilizar semelhante ótica para uma análise objetiva da sociedade contemporânea.

$\mathrm{O}$ institucionalismo dos polanyismos, que focalizamos anteriormente, não constitui a última palavra em matéria de radicalização antieconomista. Outra abordagem comparatista - a antropologia cultural de Louis Dumont - a supera a esse respeito. Nela se encontra, possivelmente, o ápice do surto economicida nas ciências humanas dos dois últimos decênios.

Em Homo aequalis, seu segundo livro maior, Dumont elogia a 'forte demonstração', devida a Polanyi, do caráter excepcional da era moderna, baseada na autonomia do econômico, enfim liberto de seu tecido social. A finalidade confessa de Dumont é ampliar essa análise, esquadrinhando a 'ideologia econômica'. Trata-se, como se percebe, de autor que se coloca nos antípodas de nossa perspectiva, pois para ele ideológico éo pensamento econômico, e não a sua rejeição na teoria sociológica.

Num primeiro tempo, Dumont destingue duas concepções sociais da riqueza. Nas sociedades tradicionais, terra e dinheiro, riqueza imobiliária, são dissociados; os direitos sobre a terra estão imbricados na organização social; as relações entre os homens prevalecem sobre as relações entre homens e coisas. Na sociedade moderna, ao contrário, a riqueza se torna uma categoria unificada, cujo mode- 
lo é sua forma mobiliária, e as relações entre homens e coisas passam para o primeiro plano.

Atrás desse contraste, Dumont discerne a dicotomia do holismo e do individualismo. Mas para ele essa dicotomia se desdobra numa segunda antítese: aquela que existe entre hierarquia e igualitarismo.

O holismo e a concepção da riqueza na sociedade tradicional estão para a hierarquia assim como 0 individualismo e a moderna idéia da riqueza estão para o igualitarismo. Acontece que para Dumont, como para Polanyi, a subordinação funcional, operacional do econômico ao social é a norma, a forma predominante de sociedade. Donde se conclui que o modo mais objetivo de elucidar o segredo de nossa sociedade - a moderna - consiste em ultrapassar nosso natural sociocentrismo, encarando a sociedade individualista e igualitária 'a partir da sociedade hierárquica'. Evidentemente, Louis Dumont, distinto hinduísta, autor do célebre Homo hierarchicus (1967), estudo importante do sistema de castas, está bem colocado para nos guiar nessa empresa de descentramento cultural. Max Weber se perguntava por que o capitalismo não nascera das civilizações não-ocidentais. Ele contemplava estas últimas do ponto de vista de uma 'falta'. Sob esse aspecto, Dumont é o anti-Weber: o Ocidente é, segundo ele, que 'perdeu' algo; o mundo não-ocidental é que constitui a regra de uma plenitude.

É forçoso admirar a arte com que nosso hinduísta conjuga a contribuição polanyiana com as grandes fórmulas evolucionistas da proto-sociologia vitoriana, como a passagem do status ao contrato em Maine ou da comunidade à sociedade ( $G e$ meinschaft / Gesellschaft) em Toennies. Por outro lado, Dumont se esforça para içar o conceito antropológico de cultura ao nivel das representacões politicas no sentido de Durkheim. Pois o que ele chama de ideologia é exatamente a cultura enquanto repreSentação coletiva. De certo ponto de vista, Dumont é alguém que tenta pensar o problema de Tocqueville - o problema da dinâmica da igualdade na sociedade moderna - com a ajuda de Durkheim.

Dumont alarga a reserva de Tocqueville face ao igualitarismo a ponto de sugerir uma patologia histórica: em última análise, nosso individualismo igualitário não passaria de uma ideologia extraviada, esquecida de que o holismo é inerente, a um só tempo, ao estado 'normal' da sociedade e à penetração sociológica.

Em particular, se a sociedade moderna é uma presa dos totalitarismos, é porque o totalitarismo é apenas uma resposta brutal a um mal-estar da civilização: é a tentativa contraditória de re-subordinar o indivíduo ao todo social, quando a sociedade que o sofre é precisamente aquela que obriga o homem a pensar-se como indivíduo isolado. O totalitarismo reflete a dilaceração íntima da sociedade individualista. O que ele desvela é uma secreta nostalgia de comunidade e de hierarquia.

Dumond estima sua crítica superior ao marxismo. Em sua opinião, Marx permaneceu muito mais um economista sociológico do que um verdadeiro sociólogo da economia - o que condenou o marxismo a ficar do lado da malsinada 'ideologia econômica', lamentavelmente igualitária e individualista...

O que impressiona, na obra de Dumont, é o preconceito antiindividualista - preconceito pouco ou nada fundado em análises convincentes da superioridade do holismo à oriental. Instigante como comparação transcultural, sua teoria falha como base para uma crítica da sociedade moderna. Mas, uma vez mais, não sem antes rebaixar e desvalorizar nossa velha vítima: o homo oeconomicus, o indivíduo racionalista e individualista gerado pela cultura ocidental.

Diante das sete teorias economicidas que examinamos, esperamos haver indicado suficientemente que o 'vilão' - o homo oeconomicus - resiste galhardamente ao poderio crítico de seus virtuosos, quando não puritanos, assassinos em potencial. Muito se poderia acrescentar, é claro, em defesa do econômico e de sua conexão, histórica e atual, com o inestimável conjunto das liberdades modernas. Mas isso são outros quinhentos, e foge ao âmbito puramente crítico desse artigo (para o leitor interessado numa justificativa sintética do valor social da lógica do econômico, permito-me sugerir meu livro A Natureza do processo, Nova Fronteira, 1982). 